\title{
sciforum
}

Conference Proceedings Paper

\section{Russian Red Data Book Orchids: What Anthropogenic Factors are Leading to their Extinction in Regions?}

\author{
Anatoliy A. Khapugin 1,2* \\ 1 Tyumen State University; Volodarskogo Street, 6, 625003, Tyumen, Tyumen region, Russia \\ 2 Joint Directorate of the Mordovia State Nature Reserve and National Park 'Smolny' ; Krasnaya Street 30, \\ 430005, Saransk, Republic of Mordovia, Russia \\ * Correspondence: hapugin88@yandex.ru
}

\begin{abstract}
The research of drivers leading to plant extinction is primary task in global biodiversity conservation. Despite Russia covers a large area, there is a lack of data on factors leading to plant extinction there, including orchids. We aimed to evaluate the anthropogenic drivers threaten orchids included in the Russian Red Data Books. For this purpose, we generalized and systematized data on orchids included in all relevant (i.e. published during recent 10-11 years) regional Red Data Books available online by 31 December 2020. For each Red Data Book orchid, we identified threats, i.e. drivers leading to species extinction, according to sections "Limiting factors" or "Limiting factors and threats" of regional Red Data Books. We found the total taxonomic list of Red Data Book orchids in the analyzed regions of Russia. The similarity of the lists of orchid taxa in analyzed regions has been established on the basis of Jaccard index. In regards of extinction drivers, we found what of them are most serious threats to orchids in the regions of Russian Federation. We believe that the conducting of the similar study for the whole amount of threatened plants of Russia will provide highly valuable results demanded all over the world.
\end{abstract}

Keywords: Orchidaceae; threat; extinction driver; plant conservation; Russia

\section{Introduction}

Extinction of species is the leading problems in biodiversity conservation at national and global levels. While an extinction of animals could be easier revealed (e.g. [1]), we need more time to prove a plant extinction event [2]. Humphreys et al. (2019) [3] stated that plant extinction studies should undoubtedly come with caveats, with indicating an underestimation of plant extinction rates, that could be explained by many unreported extinctions of poorly known taxa. Moreover, regional extinction events could be slower fixed at global assessments (e.g. Global IUCN Red List). Therefore, they play important role in estimation of plant extinctions able to be achieved at global scale through regional one.

Although Russia covers about $11.0 \%$ of total terrestrial area, there is a remarkable lack of biodiversity data from this country. This is well recordable in global reviews of biodiversity, including GBIF data [4], naturalized plants [5], ex situ plant conservation centers [6], peatland vegetation conservation [7]. We believe that it derives from low availability of biodiversity data written in Russian, being not prepared according to international publication standards. In particular, this concerns data on conservation and distribution of orchids. For instance, Khapugin (2020) [8] demonstrated that despite numerous studies of orchids in Protected Areas, there is a remarkable gap of data in Russia, even taking into account a high number of Protected Areas in this country. 
Noteworthy, threats registered for each threatened plant could be recognized as extinction drivers. At the same time, various factors influence differently to a certain plant species extinction. In this study, we aimed to assess the threats indicated for orchid taxa included in the recently published Red Data Books of Russian regions. To achieve the goal, we evaluated i) taxonomic composition of Red Data Book orchid species in Russian regions, ii) main threats leading to the extinction of orchids in Russia. We assumed that extinction of orchids, as more attractive, vulnerable and wider known plants is more influenced by such factors as direct elimination of aboveground parts of plants (bouquet gathering) and disturbance of habitats.

\section{Experiments}

To study, we sampled the Red Data Books published and/or available online in 2010-2020. This period was selected to use the most modern and relevant data. As a result, we sampled and analysed data on Red Data Book orchid taxa from 51 regions (Figure 1).

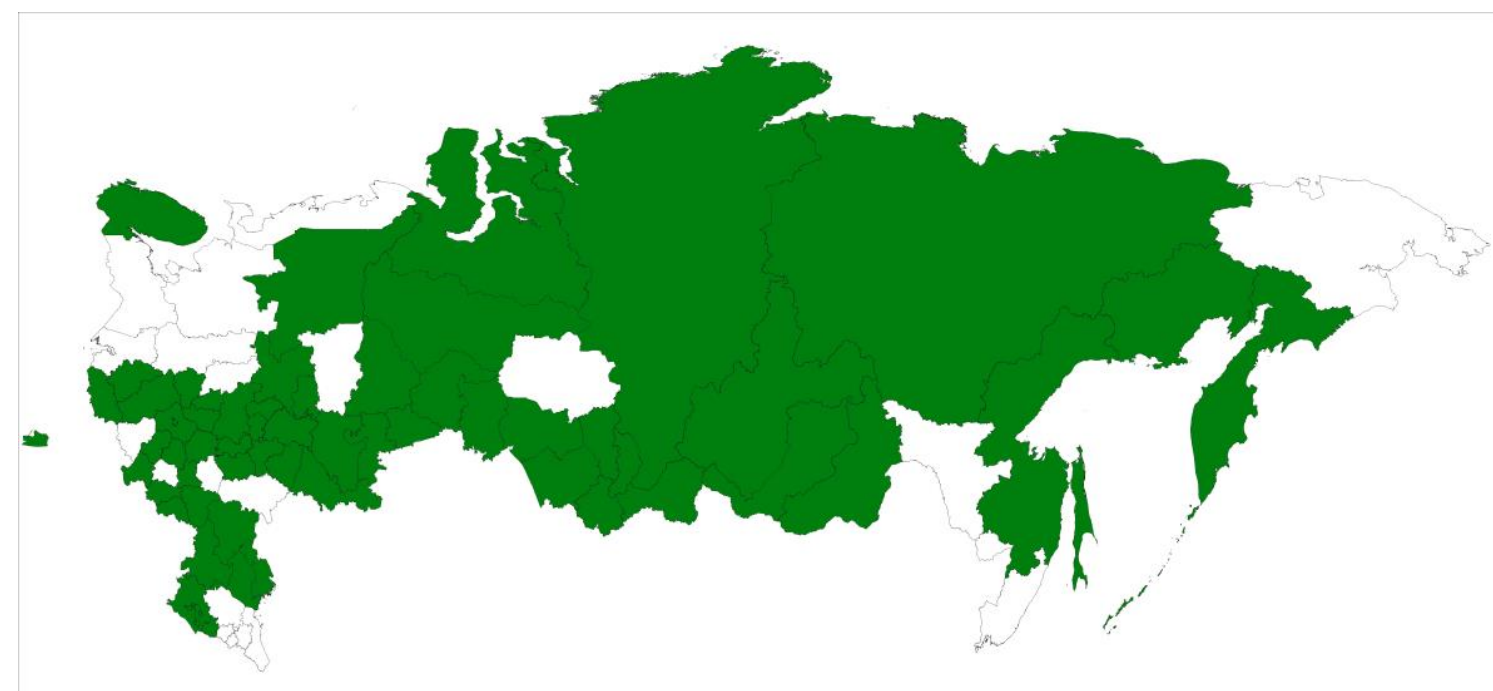

Figure 1. Map of the Russian Federation, where the sampled regions are indicated. Empty regions refer to the absence of data on Red Data Book orchids (according to [9] with modifications).

To estimate drivers leading to the orchid taxa in Russia, we analyzed sections "Limiting factors" or "Limiting factors and threats" in each Red Data Book. We did not assess and judge on the completeness and reliability of original data for each orchid included in a Red Data Book. In addition, we did not estimate the validity or reasons of the inclusion of each orchid in Red Data Books of Russian regions. For establishing a scheme of extinction drivers, we applied mainly IUCN CMP Unified Classification of Direct Threats [10], with modifications based on some relevant publications [9,11,12]. As a result, we used 12 extinction drivers, applied previously in [9], namely Agriculture, Fire, Forestry, Grazing, Habitat degradation, Habitat destruction, Hydrological disturbance, Invasion, Mining, Unknown, Urbanization, Utilization.

To standardize the scheme of scientific names, we used the database Plants of the World Online (http://www.plantsoftheworldonline.org/). For this purpose, we applied three-stage algorithm. At first stage, we ordered alphabetically all taxa. At second, scientific names of orchids were standardized according to POWO database. At third, we deleted duplicate taxa from species lists for further analysis.

The determination of the similarity of lists taxa from the regional Red Data Books using Jaccard similarity index. Jaccard's similarity index $J S=100 \times C /(A+B-C)$ was calculated, where $\mathrm{A}=$ number of species in floristic list A; B = number of species in floristic list B; C = number of species shared between two (A and B) floristic lists. For this purpose we used function "vegdist" in package "vegan" [13] in software R ver. 3.4.0 [14]. 


\section{Results and Discussion}

\subsection{Subsection}

Originally, the accumulated sum of orchid taxa in 51 Red Data Books was 1070. After taxonomic standardization according to taxonomic systems, the total taxonomic list of Red Data Book plants in 51 Russian regions contained finally 120 taxa (Appendix A). The Red Data Book orchid species richness varied across the regions, ranging from 0 in the Astrakhan Region to 44 in Krasnodarsky Krai. This is partially in accordance with Efimov (2020) [15] who demonstrated the Krasnodarsky Krai as the region with the highest number of orchid taxa in Russia. The average number of Red Data Book species per region in Russia was $18 \pm 8$ (mean \pm SD; median $=18$ ). We also found no correlation between region's area and number of Red Data Book orchids per region $(\mathrm{r}=0.0 .08, \mathrm{p}<$ 0.95). The most widespread species were Cypripedium calceolus L. (48 regions), and Orchis militaris L. (46 regions), followed by Epipactis palustris (L.) Crantz (42 regions), Ponerorchis cucullata (L.) X.H.Jin, Schuit. \& W.T.Jin (40 regions), Epipogium aphyllum Sw. (39 regions), Hammarbya paludosa (L.) Kuntze (38 regions), Liparis loeselii (L.) Rich. (35 regions), Corallorhiza trifida Châtel. (33 regions) (Appendix A). Noteworthy, orchids were demonstrated to be the most widespread among all Red Data Book plant species in Russia (see [9]). This is in accordance with data on other studies demonstrated the high vulnerability of orchids in various regions around the world (e.g. [8,16,17]).

The 120 species belong to 39 genera. The highest number of taxa was found in Dactylorhiza (17 species), Orchis (11 species), Platanthera (11 species), Neottia (10 species). Other 32 genera were represented by one (e.g. Calypso, Chamorchis, Gastrodia, Pogonia) to seven (Epipactis) species (Appendix A).

We conducted the cluster analysis (Ward method; Figure 2) of the similarity of taxonomic lists of orchids in Russian regions, based on the Jaccard index similarity. The results reflected the biogeographical position of regions, with some deviations caused by the number of Red Data Book orchids per region. In the obtained dendrogram, four groups (A, B, C, D) are distinguishable. So, the large and complicated cluster $\mathrm{A}$ is represented by regions of the centre of European Russia and regions of Urals (e.g. Sverdlovsk Region, Chelyabinsk Region) and West Siberia (e.g. Tyumen Region, Omsk Region). Cluster B includes regions of East Siberia (e.g. Krasnoyarsk Region, Irkutsk Region) and north-west of European Russia (Novgorod Region and Pskov Region). Cluster C is certainly complicated, being represented by regions of the north of European Russia (Republic of Komi and Murmansk Region) and West Siberia (Khanty-Mansi Autonomous Okrug), as well as Russian Far East (e.g. Sakhalin Region) and East Siberia (e.g. Republic of Yakutia). Finally, cluster D includes predominantly regions of the south of European Russia (e.g. Krasnodarsky Krai, Voronezh Region). In this cluster, there is a highly different sub-cluster represented by Republic of Kalmykia, Yamalo-Nenetskiy Autonomous Okrug, and Kaliningrad Region, based on very low number of orchid species per region (i.e., one, four and six taxa, respectively). These results are similar to the data demonstrated in [9], highlighted that similarity of lists of Red Data Book plants reflects the geographical position of regions. 


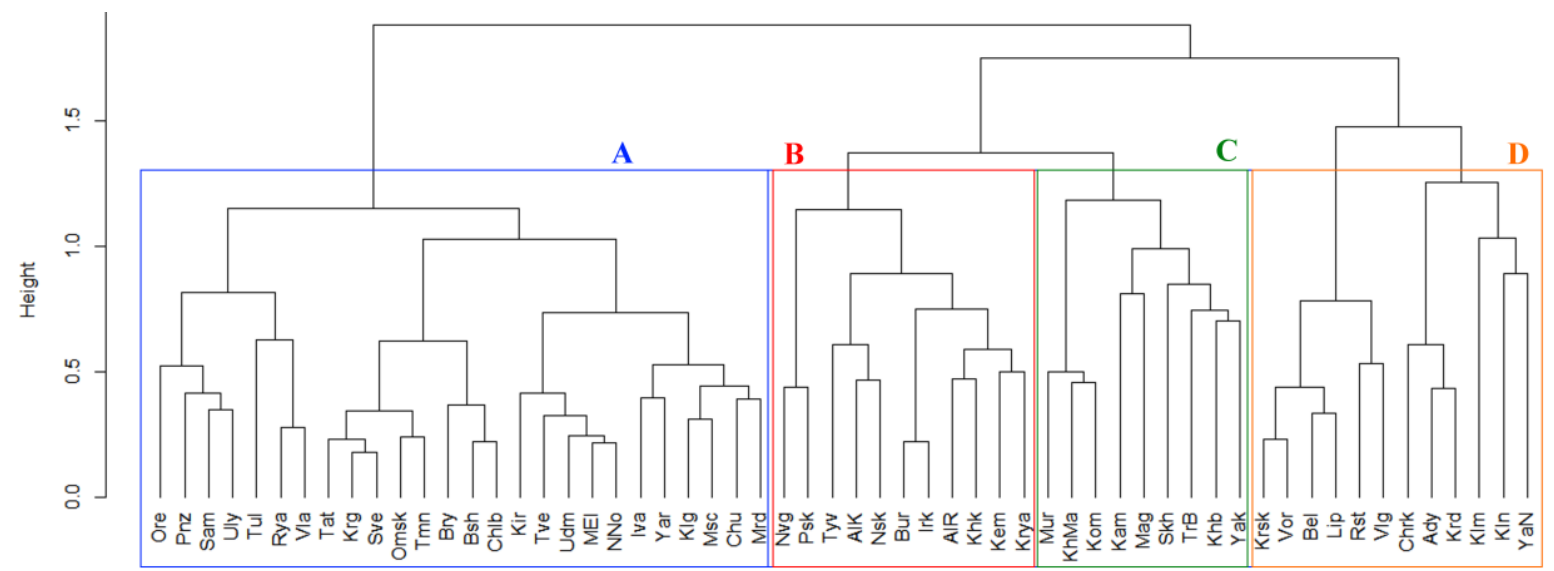

Figure 2. Cluster tree (Ward method, Euclidian distance) showing the similarity of regions based on the Jaccard index similarity of the lists of Red Data Book orchid species in Russian regions. Designations: Ady - Republic of Adygeya, AlK - Altaisky Krai, AlR - Republic of Altai, Bsh Republic of Bashkiria, Bel - Belgorod Region, Bry - Bryansk Region, Bur - Republic of Buryatia, Chlb - Chelyabinsk Region, Chrk - Republic of Karachay-Cherkessia, Chu - Republic of Chuvashia, Irk Irkutsk Region, Iva - Ivanovo Region, Kln - Kaliningrad Region, Klm - Republic of Kalmykia, Klg Kaluga Region, Kam - Kamchatsky Krai, Kem - Kemerovo Region, Khb -Khabarovsky Krai, Khk Republic of Khakassia, KhMa - Khanty-Mansi Autonomous Okrug, Kir - Kirov Region, Kom Republic of Komi, Krd - Krasnodarsky Krai, Krya - Krasnoyarsky Krai, Krg - Kurgan Region, Krsk Kursk Region, Lip - Lipetsk Region, Mag - Magadan Region, MEl - Republic of Mari El, Mrd Republic of Mordovia, Msc - Moscow Region, Mur - Murmansk Region, NNo - Nizhniy Novgorod Region, Nvg - Novgorod Region, Nsk - Novosibirsk Region, Omsk - Omsk Region, Ore - Orenburg Region, Pnz - Penza Region, Psk - Pskov Region, Rst - Rostov Region, Rya - Ryazan Region, Skh Sakhalin Region, Sam - Samara Region, Sve - Sverdlovsk Region, Tat - Republic of Tatarstan, TrB Zabaikalsky Krai, Tul - Tula Region, Tve - Tver Region, Tmn - Tyumen Region, Tyv - Republic of Tyva, Udm - Republic of Udmurtia, Uly - Ulyanovsk Region, Vla - Vladimir Region, Vlg Volgograd Region, Vor - Voronezh Region, Yak - Republic of Yakutia, YaN - Yamalo-Nenetskiy Autonomous Okrug, Yar - Yaroslavl Region.

\subsection{Extinction drivers leading to the extinction of Red Data Book orchid species}

Up to now, many studies demonstrated that habitat destruction and ecosystem overexploitation are major extinction drivers of plants and animals [18]. Based on our results, it was found that main drivers leading to extinction of orchids are generally the same that are known for all plants in various regions of the world $[9,12,19]$. Undoubtedly, various factors cause different influence on the possibility of orchid extinction. If we have these data, we may judge on measures counteracting to the disappearance of plants in certain regions. In our study, we revealed that among considered extinction drivers, habitat degradation (19.8\%), hydrological disturbance (15.6\%), urbanization $(15.0 \%)$, and utilization $(14.8 \%)$ play key roles in extinction of Red Data Book orchid species in Russia resulting from multiple drivers (Figure 3). 


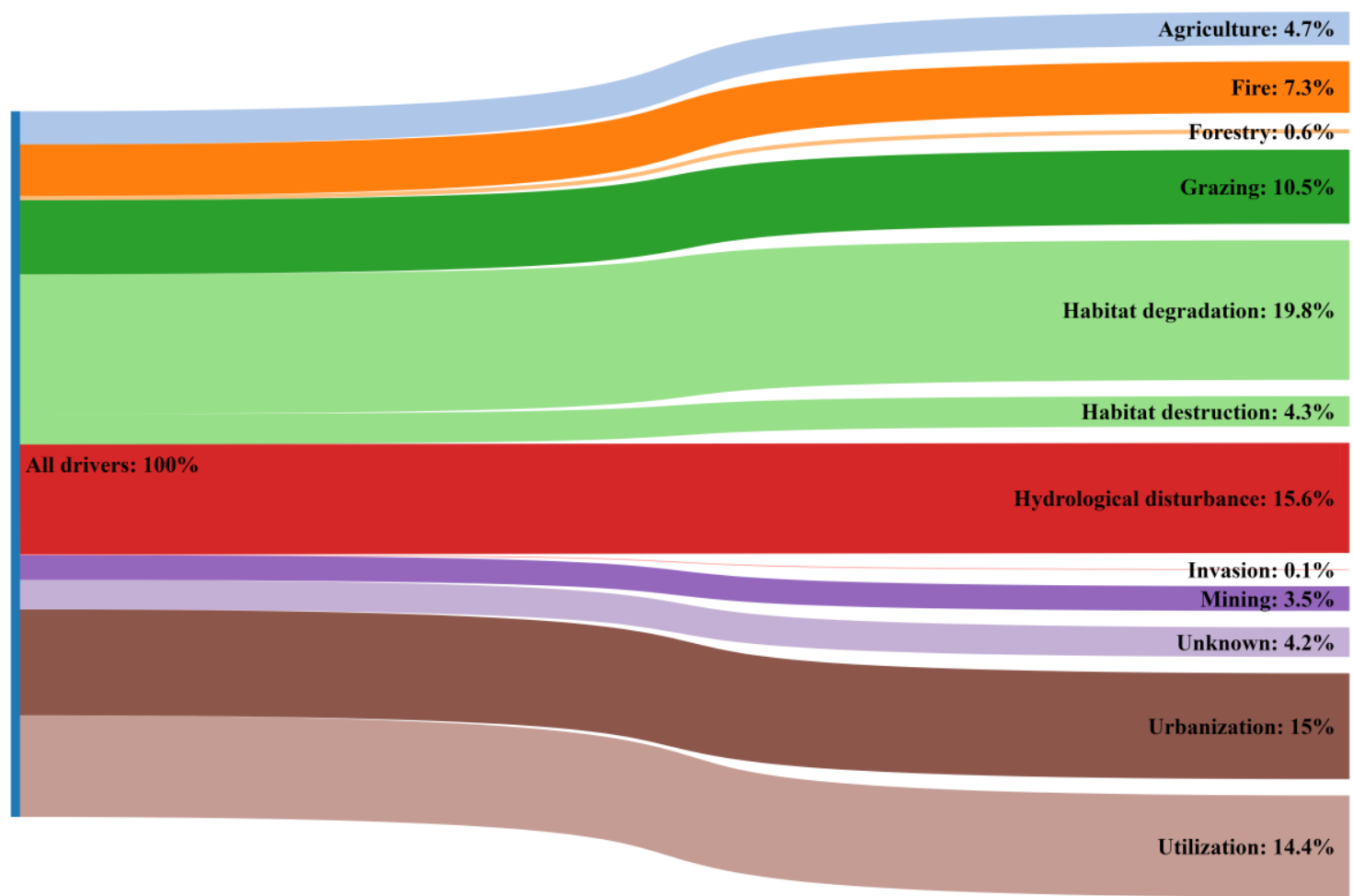

Figure 3. Primary drivers leading to orchid extinctions in Russia according to lists of Red Data Books of Russian regions.

Noteworthy, having data on plant extinction in Russia [9] and in worldwide [12], we may compare them with data on drivers causing orchid extinction in Russia. So, driver "Unknown" is a bit lower than for all Red Data Book plants in Russia (8.1\%, see [9]) and even much lower than in global scale $(48.3 \%$, see [12]). This could be explained by high attractiveness and vulnerability of orchids around the world, that reflects the increased attention to these plants. In its turn, the high attractiveness is a reason, why drivers "Urbanization" and especially "Utilization" (including gathering for bouquets, and/or attempts to introduce orchids in backyards) (e.g. [20,21]).

The high proportion of the driver "Hydrological disturbance" is in accordance with data on sensitivity of orchids to this factor around the world. So, it was found the fruit set is influenced by precipitation amount $[22,23]$. The ground water level (e.g. [24]), as well as drought conditions (e.g. [25]) are also crucial for a number of orchid species.

The most impactful driver was "Habitat degradation", which also coincides with data on orchids in various regions of the world (e.g. [21,26-29]). Despite of the mentioned above, other drivers could influence considerably on various parameters of orchid populations, including "Grazing" (e.g. [28,30]), or "Fire" (e.g. 21,31]).

\section{Conclusions}

Our study of drivers leading to the orchid extinction of orchids contributes considerably the biodiversity conservation in Russia. Despite of a high number of Russian-language publications on orchid distribution and conservation, there was a lack in data on factors causing orchid extinction in the whole Russia. Our study could be considered as an attempt to estimate the drivers using internationally applied schemes (e.g. [9,12]) for orchids in Russia. Our results are considered as a basis for creation a national classification of threats to plants.

The data on threats to Red Data Book orchids in Russian regions could fill the gaps in the global knowledge on drivers leading to national extinction of orchid species. This is in accordance with data on extinction drivers in both Russian and global scale, where we found habitat degradation, 
hydrological disturbance, urbanization, and utilization to be leading factors threatening orchids in Russian regions. In compare to data on plant extinction in global and Russian scale, we found that orchids are more susceptible to direct elimination of aboveground parts of orchids (utilization and grazing), disturbance of habitats (urbanization, habitat degradation), and changes in water regime (hydrological disturbance). Expectedly, the geographical position of regions is associated with the species composition of orchid floras in these regions. On the basis of our results, we suggest conducting more detail studies of factors affecting or leading to species extinction of plants and particular plant groups (e.g. families, genera) in Russia or in wider area.

Acknowledgments: This study was performed within the framework of the state assignment FEWZ-2020-0009 from Ministry of Education and Science of the Russian Federation

Conflicts of Interest: The author declares no conflict of interest.

\section{Appendix A}

Table A1. Taxonomic composition of Red Data Book orchids in the 51 studied regions of Russia.

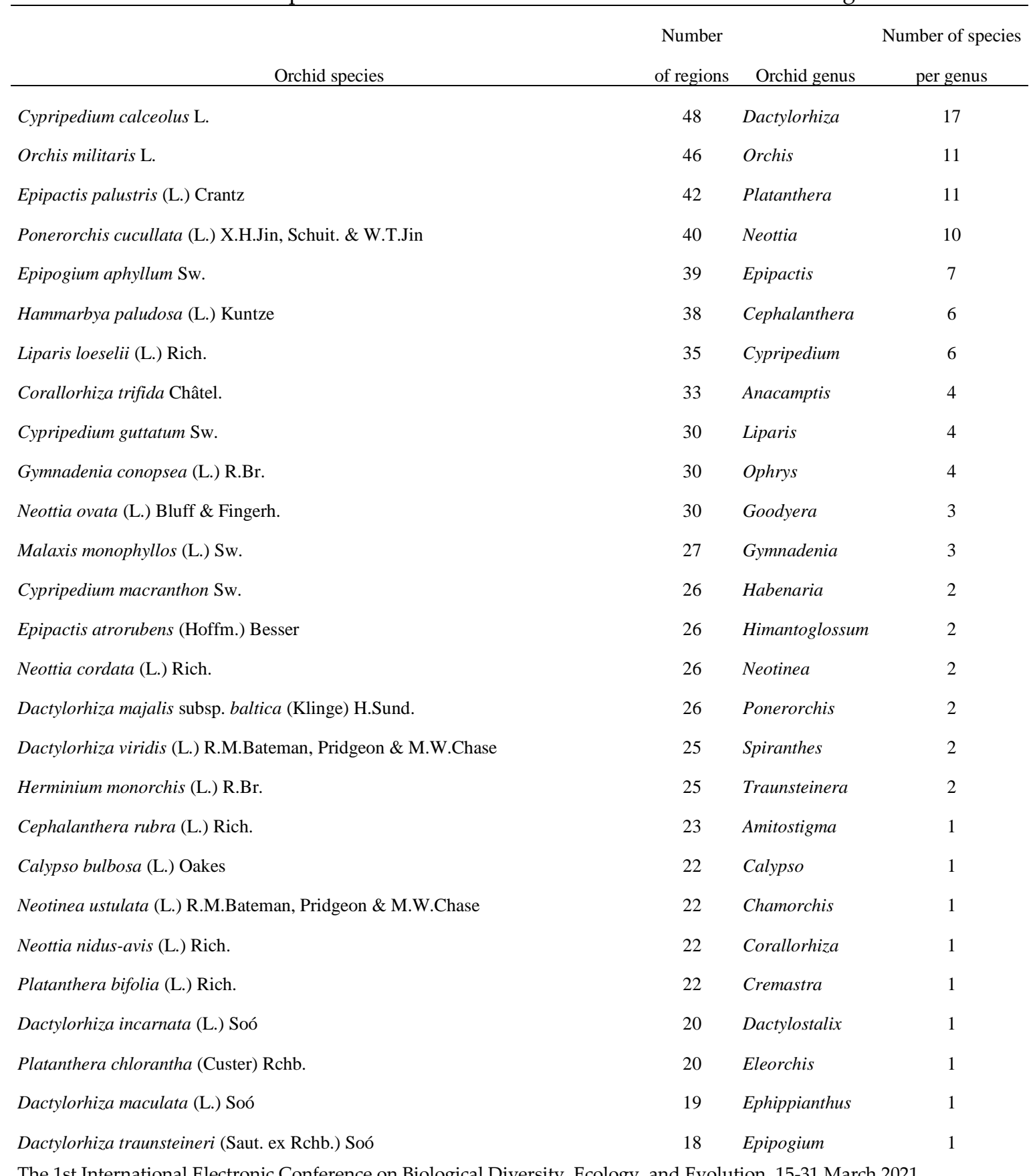

The 1st International Electronic Conference on Biological Diversity, Ecology, and Evolution, 15-31 March 2021 
The 1st International Electronic Conference on Biological Diversity, Ecology, and Evolution, 15-31 March 2021

\begin{tabular}{|c|c|c|c|}
\hline Orchid species & $\begin{array}{l}\text { Number } \\
\text { of regions }\end{array}$ & Orchid genus & $\begin{array}{c}\text { Number of species } \\
\text { per genus }\end{array}$ \\
\hline Epipactis helleborine (L.) Crantz & 18 & Galearis & 1 \\
\hline Goodyera repens (L.) R.Br. & 18 & Gastrodia & 1 \\
\hline Dactylorhiza fuchsii (Druce) Soó & 17 & Hammarbya & 1 \\
\hline Dactylorhiza incarnata subsp. cruenta (O.F.Müll.) P.D.Sell & 17 & Herminium & 1 \\
\hline Cypripedium $\times$ ventricosum $\mathrm{Sw}$. & 12 & Limodorum & 1 \\
\hline Dactylorhiza russowii (Klinge) Holub & 12 & Malaxis & 1 \\
\hline Cephalanthera longifolia (L.) Fritsch & 11 & Myrmechis & 1 \\
\hline Orchis mascula (L.) L. & 10 & Neolindleya & 1 \\
\hline Spiranthes sinensis (Pers.) Ames & 10 & Oreorchis & 1 \\
\hline Anacamptis coriophora (L.) R.M.Bateman, Pridgeon \& M.W.Chase & 9 & Pogonia & 1 \\
\hline Anacamptis palustris (Jacq.) R.M.Bateman, Pridgeon \& M.W.Chase & 7 & Pseudorchis & 1 \\
\hline Ophrys insectifera $\mathrm{L}$. & 7 & Serapias & 1 \\
\hline Platanthera fuscescens (L.) Kraenzl. & 6 & Steveniella & 1 \\
\hline Platanthera obtusata subsp. oligantha (Turcz.) Hultén & 5 & & \\
\hline Cephalanthera damasonium (Mill.) Druce & 4 & & \\
\hline Dactylorhiza fuchsii subsp. hebridensis (Wilmott) Soó & 4 & & \\
\hline Neottia camtschatea (L.) Rchb.f. & 4 & & \\
\hline Anacamptis pyramidalis (L.) Rich. & 3 & & \\
\hline Dactylorhiza urvilleana (Steud.) H.Baumann \& Künkele & 3 & & \\
\hline Gymnadenia odoratissima (L.) Rich. & 3 & & \\
\hline Limodorum abortivum (L.) Sw. & 3 & & \\
\hline Neolindleya camtschatica (Cham.) Nevski & 3 & & \\
\hline Neotinea tridentata (Scop.) R. M. Bateman, Pridgeon \& M. W. Chase & 3 & & \\
\hline Orchis picta Raf. & 3 & & \\
\hline Pseudorchis albida (L.) Á.Löve \& D.Löve & 3 & & \\
\hline Traunsteinera sphaerica (M.Bieb.) Schltr. & 3 & & \\
\hline Anacamptis morio (L.) R.M.Bateman, Pridgeon \& M.W.Chase & 2 & & \\
\hline Cypripedium shanxiense S.C.Chen & 2 & & \\
\hline Cypripedium yatabeanum Makino & 2 & & \\
\hline Dactylorhiza incarnata subsp. ochroleuca (Wüstnei ex Boll) P.F.Hunt \& Summerh. & 2 & & \\
\hline Dactylorhiza majalis (Rchb.) P.F.Hunt \& Summerh. & 2 & & \\
\hline Dactylorhiza romana subsp. georgica (Klinge) Soó ex Renz \& Taubenheim & 2 & & \\
\hline Dactylorhiza salina (Turcz. ex Lindl.) Soó & 2 & & \\
\hline Dactylorhiza traunsteineri subsp. curvifolia (F.Nyl.) Soó & 2 & & \\
\hline Eleorchis japonica (A.Gray) Maek. & 2 & & \\
\hline Ephippianthus sachalinensis Rchb.f. & 2 & & \\
\hline Gastrodia elata Blume & 2 & & \\
\hline Gymnadenia $\times$ densiflora (Wahlenb.) A.Dietr. & 2 & & \\
\hline Habenaria linearifolia Maxim. & 2 & & \\
\hline
\end{tabular}


The 1st International Electronic Conference on Biological Diversity, Ecology, and Evolution, 15-31 March 2021

\begin{tabular}{|c|c|c|c|}
\hline Orchid species & $\begin{array}{r}\text { Number } \\
\text { of regions }\end{array}$ & Orchid genus & $\begin{array}{c}\text { Number of species } \\
\text { per genus }\end{array}$ \\
\hline Orchis pallens $\mathrm{L}$. & 2 & & \\
\hline Orchis purpurea Huds. & 2 & & \\
\hline Orchis simia Lam. & 2 & & \\
\hline Orchis spitzelii Saut. ex W.D.J.Koch & 2 & & \\
\hline Oreorchis patens (Lindl.) Lindl. & 2 & & \\
\hline Platanthera chorisiana (Cham.) Rchb.f. & 2 & & \\
\hline Platanthera densa Freyn & 2 & & \\
\hline Platanthera ophrydioides F.Schmidt & 2 & & \\
\hline Platanthera tipuloides (L.f.) Lindl. & 2 & & \\
\hline Pogonia japonica Rchb.f. & 2 & & \\
\hline Ponerorchis chusua (D.Don) Soó & 2 & & \\
\hline Steveniella satyrioides (Spreng.) Schltr. & 2 & & \\
\hline Amitostigma kinoshitae (Makino) Schltr. & 1 & & \\
\hline Cephalanthera cucullata Boiss. \& Heldr. & 1 & & \\
\hline Cephalanthera erecta (Thunb.) Blume & 1 & & \\
\hline Cephalanthera longibracteata Blume & 1 & & \\
\hline Chamorchis alpina (L.) Rich. & 1 & & \\
\hline Cremastra appendiculata var. variabilis (Blume) I.D.Lund & 1 & & \\
\hline Dactylorhiza fuchsii subsp. psychrophila (Schltr.) Holub & 1 & & \\
\hline Dactylorhiza sambucina (L.) Soó & 1 & & \\
\hline Dactylostalix ringens $\mathrm{Rchb} . \mathrm{f}$. & 1 & & \\
\hline Epipactis condensata Boiss. ex D.P.Young & 1 & & \\
\hline Epipactis microphylla (Ehrh.) Sw. & 1 & & \\
\hline Epipactis papillosa Franch. \& Sav. & 1 & & \\
\hline Epipactis pontica Taubenheim & 1 & & \\
\hline Galearis cyclochila (Franch. \& Sav.) Soó & 1 & & \\
\hline Goodyera henryi Rolfe & 1 & & \\
\hline Goodyera schlechtendaliana Rchb.f. & 1 & & \\
\hline Habenaria yezoensis H.Hara & 1 & & \\
\hline Himantoglossum caprinum (M.Bieb.) Spreng. & 1 & & \\
\hline Himantoglossum comperianum (Steven) P.Delforge & 1 & & \\
\hline Liparis kumokiri F.Maek. & 1 & & \\
\hline Liparis loeselii subsp. sachalinensis (Nakai) Efimov & 1 & & \\
\hline Liparis makinoana Schltr. & 1 & & \\
\hline Myrmechis japonica (Rchb.f.) Rolfe & 1 & & \\
\hline Neottia acuminata Schltr. & 1 & & \\
\hline Neottia convallarioides (Sw.) Rich. & 1 & & \\
\hline Neottia krasnojarica Antipova & 1 & & \\
\hline Neottia papilligera Schltr. & 1 & & \\
\hline
\end{tabular}




\begin{tabular}{|c|c|c|c|}
\hline Orchid species & $\begin{array}{r}\text { Number } \\
\text { of regions }\end{array}$ & Orchid genus & $\begin{array}{c}\text { Number of species } \\
\text { per genus }\end{array}$ \\
\hline Neottia pinetorum (Lindl.) Szlach. & 1 & & \\
\hline Neottia puberula (Maxim.) Szlach. & 1 & & \\
\hline Ophrys apifera Huds. & 1 & & \\
\hline Ophrys caucasica Woronow ex Grossh. & 1 & & \\
\hline Ophrys sphegodes subsp. mammosa (Desf.) Soó ex E.Nelson & 1 & & \\
\hline Orchis $\times$ colemanii Cortesi & 1 & & \\
\hline Orchis $\times$ wulffiana Soó & 1 & & \\
\hline Orchis provincialis Balb. ex Lam. \& DC. & 1 & & \\
\hline Orchis punctulata Steven ex Lindl. & 1 & & \\
\hline Platanthera bifolia subsp. extremiorientalis (Nevski) Soó & 1 & & \\
\hline Platanthera maximowicziana Schltr. & 1 & & \\
\hline Platanthera sachalinensis F.Schmidt & 1 & & \\
\hline Serapias vomeracea (Burm.f.) Briq. & 1 & & \\
\hline Spiranthes spiralis (L.) Chevall. & 1 & & \\
\hline Traunsteinera globosa (L.) Rchb. & 1 & & \\
\hline
\end{tabular}

\section{References}

1. Burbidge, A.A.; Manly, F.J. Mammal extinctions on Australian islands: causes and conservation implications. Journal of Biogeography 2002, 29(4), 465-473. https://doi.org/10.1046/j.1365-2699.2002.00699.x

2. Cronk, Q. Plant extinctions take time. Science 2016, 353(6298), $446-447$. https://doi.org/10.1126/science.aag1794

3. Humphreys, A.M.; Govaerts, R.; Ficinski, S.Z.; Nic Lughadha, E.; Vorontsova, M.S. Global dataset shows geography and life form predict modern plant extinction and rediscovery. Nature Ecology and Evolution 2019, 3(7), 1043-1047. https://doi.org/10.1038/s41559-019-0906-2

4. Yesson, C.; Brewer, P.W.; Sutton, T.; Caithness, N.; Pahwa, J.S.; Burgess, M.; Gray, W.A.; White, R.J.; Jones, A.C.; Bisby, F.A.; Culham, A. How global is the global biodiversity information facility?. PloS ONE 2007, 2(11), e1124. https://doi.org/10.1371/journal.pone.0001124

5. Pyšek, P.; Pergl, J.; Essl, F.; Lenzner, B.; Dawson, W.; Kreft, H.; Weigelt, P.; Winter, M.; Kartesz, J.; Nishino, M.; Antonova, L.A.; Barcelona, J.F.; Cabezas, F.J.; Cárdenas, D.; Cárdenas-Toro, J.; Castańo, N.; Chacón, E.; Chatelain, C.; Dullinger, S.; Ebel, A.L.; Figueiredo, E.; Fuentes, N.; Genovesi, P.; Groom, Q.J.; Henderson, L.; Inderjit; Kupriyanov, A.; Masciadri, S.; Maurel, N.; Meerman, J.; Morozova, O.; Moser, D.; Nickrent, D.; Nowak, P.M.; Pagad, S.; Patzelt, A.; Pelser, P.B.; Seebens, H.; Shu, W.; Thomas, J.; Velayos, M.; Weber, E.; Wieringa, J.J.; Baptiste, M.P.; van Kleunen, M. Naturalized alien flora of the world: species diversity, taxonomic and phylogenetic patterns, geographic distribution and global hotspots of plant invasion. Preslia 2017, 89, 203-274. https://doi.org/10.23855/preslia.2017.203

6. Mounce, R.; Smith, P.; Brockington, S. Ex situ conservation of plant diversity in the world's botanic gardens. Nature Plants 2017, 3(10), 795-802. https://doi.org/10.1038/s41477-017-0019-3

7. Taylor, N.G.; Grillas, P.; Fennessy, M.S.; Goodyer, E.; Graham, L.L.B.; Karofeld, E.; Lindsay, R.A.; Locky, D.A.; Ockendon, N.; Rial, A.; Ross, S.; Smith, R.K.; van Diggelen, R.; Whinam, J.; Sutherland, W.J. A synthesis of evidence for the effects of interventions to conserve peatland vegetation: overview and critical discussion. Mires and Peat 2019, 24, 18.

8. Khapugin, A.A. A global systematic review on orchid data in Protected Areas. Nature Conservation Research 2020, 5(Suppl.1), 19-33. https://dx.doi.org/10.24189/ncr.2020.019 
9. Khapugin, A.A.; Kuzmin, I.V.; Silaeva, T.B. Anthropogenic drivers leading to regional extinction of threatened plants: insights from regional Red Data Books of Russia. Biodiversity and Conservation 2020, 29(8), 2765-2777. https://dx.doi.org/10.1007/s10531-020-02000-x

10. Salafsky, N.; Salzer, D.; Stattersfield, A.J.; Hilton-Taylor, C.; Neugarten, R.; Butchart, S.H.M.; Collen, B.; Cox, N.; Master, L.L.; O'Connor, S.; Wilkie, D. A Standard Lexicon for Biodiversity Conservation: Unified Classifications of Threats and Actions. Conservation Biology 2008, 22(4), 897-911. https://doi.org/10.1111/j.1523-1739.2008.00937.x

11. Aedo, C.; Medina, L.; Barberá, P.; Fernández-Albert, M. Extinctions of vascular plants in Spain. Nordic Journal of Botany 2015, 33(1), 83-100. https://doi.org/10.1111/njb.00575

12. Le Roux, J.J.; Hui, C.; Castillo, M.L.; Iriondo, J.M.; Keet, J.H.; Khapugin, A.A.; Médail, F.; Rejmánek, M.; Theron, G.; Yannelli, F.A.; Hirsch, H. Recent Anthropogenic Plant Extinctions Differ in Biodiversity Hotspots and Coldspots. Current Biology 2019, 29(17), 2912-2918. https://doi.org/10.1016/j.cub.2019.07.063

13. Oksanen, J.; Blanchet, F.G.; Friendly, M.; Kindt, R.; Legendre, P.; McGlinn, D.; Minchin, P.R.; O'Hara, R.B.; Simpson, G.L.; Solymos, P.; Henry, M.; Stevens, H.; Szoecs, E.; Wagner, H. vegan: Community Ecology Package. R package version 2.4-3. 2019. Available online: https:/CRAN.Rproject.org/package=vegan

14. R Core Team. R: A language and environment for statistical computing. R Foundation for Statistical Computing, Vienna, Austria, 2020. Available online: https://www.R-project.org/

15. Efimov, P.G. Orchids of Russia: annotated checklist and geographic distribution. Nature Conservation Research 2020, 5(Suppl.1), 1-18. https://dx.doi.org/10.24189/ncr.2020.018

16. Khapugin, A.A.; Chugunov, G.G.; Vargot E.V. Cypripedium calceolus (Orchidaceae) in Central Russia: a case study for its populations in two Protected Areas in the Republic of Mordovia (Russia). Lankesteriana 2017, 17(3), 403-417. https://dx.doi.org/10.15517/lank.v17i3.31577

17. Juiling, S.; Leon, S.K.; Jumian, J.; Tsen, S.; Lee, Y.L.; Khoo, E.; Sugau, J.B.; Nilus, R.; Pereira, J.T.; Damit, A.; Tanggaraju, S.; O’Byrne, P.; Sumail, S.; Mujih, H.; Maycock, C.R. Conservation assessment and spatial distribution of endemic orchids in Sabah, Borneo. Nature Conservation Research 2020, 5(Suppl.1), 136-144. https://dx.doi.org/10.24189/ncr.2020.053

18. Pimm, S.; Raven, P.; Peterson, A.; Sekercioglu, C.H.; Ehrlich, P.R. Human impacts on the rates of recent, present, and future bird extinctions. Proceedings of the National Academy of Sciences 2006, 103(29), 10941-10946. https://doi.org/10.1073/pnas.0604181103; 9,12

19. Corlett, R.T. Plant diversity in a changing world: Status, trends, and conservation needs. Plant Diversity 2016, 38(1), 10-16. https://doi.org/10.1016/j.pld.2016.01.001

20. Perazza, G.; Decarli, M. Monitoring of Cypripedium calceolus (Orchidaceae) in the Adamello-Brenta Natural Park (Italy). Nature Conservation Research 2020, 5(Suppl.1), 178-184. https://dx.doi.org/10.24189/ncr.2020.045

21. Wraith, J.; Pickering, C. A continental scale analysis of threats to orchids. Biological Conservation 2019, 23, 7-17. https://doi.org/10.1016/j.biocon.2019.03.015

22. Kirillova, I.A.; Kirillov, D.V. Impact of weather conditions on seasonal development, population structure and reproductive success on Dactylorhiza traunsteineri (Orchidaceae) in the Komi Republic (Russia). Nature Conservation Research 2020, 5(Suppl.1), 77-89. https://dx.doi.org/10.24189/ncr.2020.016

23. Bleho, B.I.; Borkowsky, C.L.; Grantham, M.A.; Hamel, C.D. A 20 y Analysis of Weather and Management Effects on a Small White Lady's-slipper (Cypripedium candidum) Population in Manitoba. The American Midland Naturalist 2021, 185(1), 32-48. https://doi.org/10.1637/0003-0031-185.1.32

24. Grootjans, A.; Shahrudin, R.; van de Craats, A.; Kooijman, A.; Oostermeijer, G.; Petersen, J.; Amatirsat, D.; Bland, C.; Stuyfzand, P.. Window of opportunity of Liparis loeselii populations during vegetation succession on the Wadden Sea islands. Journal of Coastal Conservation 2017, 21, 631-641. https://doi.org/10.1007/s11852-016-0448-6

25. Guevara-Perez, C.I.; Delgado-Sánchez, P.; Torres-Castillo, J.A.; Flores-Rivas, J.D.; Mendieta-Leiva, G.; Rosa-Manzano, E.D.. Epiphytic orchids Stanhopea tigrina and Prosthechea cochleata are differentially affected by drought in a subtropical cloud forest. Photosynthetica 2019, 57(4), 1053-1065. https://doi.org/10.32615/ps.2019.123

26. Lohani, N.; Tewari, L.M.; Joshi, G.C.; Kumar, R.; Kishor, K.; Upreti, B.M. Population assessment and threat categorization of endangered medicinal orchid Malaxis acuminata D. Don. from north-west Himalaya. International Journal of Conservation Science 2013, 4(4), 483-492. 
27. De Beenhouwer, M.; Aerts, R.; Hundera, K.; Van Overtveld, K.; Honnay, O. Management intensification in Ethiopian coffee forests is associated with crown habitat contraction and loss of specialized epiphytic orchid species. Basic and Applied Ecology 2015, 16(7), 592-600. https://doi.org/10.1016/j.baae.2015.06.006

28. Tatarenko, I.; Dodd, M.; Wallace, H.; Bellamy, G.; Fleckney, A. Protecting small populations of rare species. Case study on Dactylorhiza viridis (Orchidaceae) in Fancott Woods and Meadows SSSI, Bedfordshire, UK. Nature Conservation Research 2020, 5(Suppl.1), 165-171. https://dx.doi.org/10.24189/ncr.2020.028

29. Kolanowska, M.; Jakubska-Busse, A. Is the lady's-slipper orchid (Cypripedium calceolus) likely to shortly become extinct in Europe? - Insights based on ecological niche modelling. PLoS ONE 2020, 15(1), e0228420. https://dx.doi.org/10.1371/journal.pone.0228420

30. Romano, V.A.; Rosati, L.; Fascetti, S. Trends in population size of Ophrys argolica subsp. biscutella in the Appennino Lucano-Val d'Agri-Lagonegrese National Park (Italy). Nature Conservation Research 2020, 5(Suppl.1), 155-164. https://dx.doi.org/10.24189/ncr.2020.058

31. Brundrett, M.C. Using vital statistics and core-habitat maps to manage critically endangered orchids in the Western Australian wheatbelt. Australian Journal of Botany 2016, 64, 51-64. https://doi.org/10.1071/BT15087

(C) 2020 by the authors; licensee MDPI, Basel, Switzerland. This article is an open access article distributed under the terms and conditions of the Creative Commons by Attribution (CC-BY) license (http://creativecommons.org/licenses/by/4.0/). 